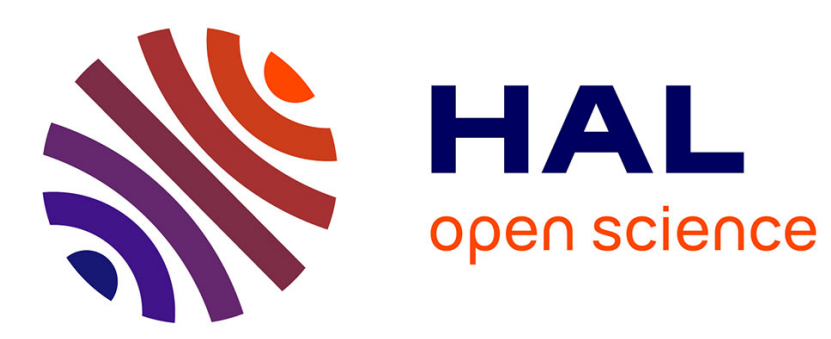

\title{
Sacrifice ratio dispersion within the Euro Zone: what can be learned about implementing a single monetary policy
}

\author{
Jean-Jacques Durand, Marilyne Huchet, Julien Licheron
}

\section{To cite this version:}

Jean-Jacques Durand, Marilyne Huchet, Julien Licheron. Sacrifice ratio dispersion within the Euro Zone: what can be learned about implementing a single monetary policy. International Review of Applied Economics, 2008, 22 (5), pp.601-621. 10.1080/02692170802287672 . hal-01462338

\section{HAL Id: hal-01462338 \\ https://hal.science/hal-01462338}

Submitted on 30 May 2020

HAL is a multi-disciplinary open access archive for the deposit and dissemination of scientific research documents, whether they are published or not. The documents may come from teaching and research institutions in France or abroad, or from public or private research centers.
L'archive ouverte pluridisciplinaire HAL, est destinée au dépôt et à la diffusion de documents scientifiques de niveau recherche, publiés ou non, émanant des établissements d'enseignement et de recherche français ou étrangers, des laboratoires publics ou privés. 


\title{
Sacrifice ratio dispersion within the Euro Zone:
}

\section{What can be learned about implementing a Single Monetary Policy?}

\section{Jean-Jacques DURAND ${ }^{\mathrm{a}}$, Marilyne HUCHET-BOURDON ${ }^{\mathrm{b}, c_{*}}$ and Julien LICHERON ${ }^{\mathrm{a}}$}

\begin{abstract}
This article focuses on the comparison of sacrifice ratios as an indicator for structural dispersion within the euro area over the period 1972-2003. Estimates of the sacrifice ratio, defined as the cumulative output cost arising from permanent inflation reduction, are obtained using structural VAR models. Results from sub-period analysis as well as ten-year-period rolling estimates lead to two main conclusions. Firstly empirical evidence displays a recent increase in the average sacrifice ratio, which can be linked to the simultaneous decrease in the average inflation rate: this negative relationship between the initial level of inflation and the cost of disinflation can be seen as a justification for the choice of an inflation objective close to $2 \%$ for the European Central Bank (ECB) rather than a target of perfect price stability, potentially very damaging. Secondly, we can't provide evidence of any reduction in European sacrifice ratio dispersion, which would suggest that the nominal convergence triggered by the Maastricht Treaty didn't involve a true reduction of structural differences. It is likely to be a problem in the stance of a single monetary policy, since structural differences imply asymmetric responses of real national economies to the same monetary impulse.
\end{abstract}

Keywords: Sacrifice ratio; monetary policy; convergence; Economic and Monetary Union (EMU)

\footnotetext{
${ }^{\text {a }}$ University Rennes 1, CREM, CNRS, UMR 6211, Faculty of Economics, 7 place Hoche, CS 86514, 35065 Rennes cedex, France. E-mail : jean-jacques.durand@univ-rennes1.fr, julien.licheron@univ-rennes1.fr

${ }^{\mathrm{b}}$ AGROCAMPUS OUEST, UMR1302, F-35000 Rennes, France

${ }^{\mathrm{c}}$ CREM CNRS UMR6211

*Corresponding Author: Marilyne Huchet-Bourdon, AGROCAMPUS OUEST, UMR SMART, 65 rue de St Brieuc, CS 84215, 35042 Rennes cedex, France. E-mail : marilyne.huchet-bourdon@agrocampus-ouest.fr
} of Applied Economics, 22 (5), 601-621. DOI : 10.1080/02692170802287672 


\section{Introduction}

The disinflation policies implemented throughout the 1980s and 1990s have led many observers to wonder about the true cost, in terms of real activity, resulting from a significant and permanent reduction of inflation. The issue of the transitory output cost associated with a restrictive monetary policy remains an endless debate among economists. Recent theoretical studies have focused on the key determinants of disinflation costs: the lack of central bank credibility, slow adjustments of inflation expectations to changes in monetary policy, imperfect information, and wages and prices stickiness, can all lead to high adjustment costs during a disinflation process. This would explain the benefit of evaluating these short-term costs through the estimation of a "sacrifice ratio", typically defined as the cumulative output loss, measured as a percent of one-year real Gross Domestic Product (GDP), arising from a one-percentage-point permanent reduction in the inflation rate. Empirical results from the literature confirm that sacrifice ratios may differ widely from one country to another (for a given calculation method and over the same period). Sacrifice ratios can therefore be viewed as indicators of structural differences between countries.

The present paper investigates this topic for the twelve countries belonging to the Economic and Monetary Union (EMU). The single monetary policy led by the European Central Bank (ECB) and adopted in 1999 has been assigned the aim of maintaining price stability within the euro area taken as a whole (i.e. maintaining the aggregate inflation rate below 2\%). One of the chief concerns lies in the effects of such a policy on national economies. It can easily be understood that if sacrifice ratios were to differ broadly among EMU member states, the common monetary policy would then produce asymmetric effects on national outputs. Such asymmetries would complicate the task of the ECB. Has the nominal convergence required for candidate countries to participate in the euro currency (as enforced by the convergence criteria defined in the 1992 Maastricht Treaty) translated into a structural convergence that could reduce these asymmetries? An analysis of sacrifice ratio dynamics within the euro area should help answer these questions.

In this paper, we try to calculate and use the dispersion of sacrifice ratios among the twelve EMU of Applied Economics, 22 (5), 601-621. DOI : 10.1080/02692170802287672 
countries as an indicator for structural convergence. Our paper is therefore related to the works from Andersen \& Wascher (1999), Boone \& Mojon (1998) and Cuñado \& de Gracia (2003), but our contribution is twofold. Firstly, we focus on EMU countries and try to assess the evolution of structural dispersion looking at the dynamics of sacrifice ratios dispersion both across countries and over time. The analysis of a long period 1973-2003 and the use of ten-year rolling estimates should clearly provide some insights. Secondly, we use a structural VAR methodology inspired from Cecchetti (1994) and Cecchetti \& Rich (2001) to calculate sacrifice ratios, since this methodology is suitable for international comparisons.

The remainder of this paper is structured as follows. The next section focuses on the concept of a sacrifice ratio. Section 3 presents our empirical modelling approach, and Section 4 discusses the pertinent results. Section 5 provides some concluding remarks.

\section{The Sacrifice Ratio}

The sacrifice ratio can be defined as the cumulative output cost resulting from a-one percentage-point reduction in the inflation rate. This definition of the sacrifice ratio may be illustrated simply. Figure 1 shows one possible path for output and inflation following a tightening in monetary policy that ultimately lowers the inflation rate by one percentage point. The sacrifice ratio is equal to the sum of output gaps (i.e. the gaps between actual and potential output) expressed as a percent of GDP. This sum is equivalent to the output loss in the shaded area. 
Figure 1. Hypothetical responses of output and inflation during a disinflation process (inspired by Filardo, 1998)

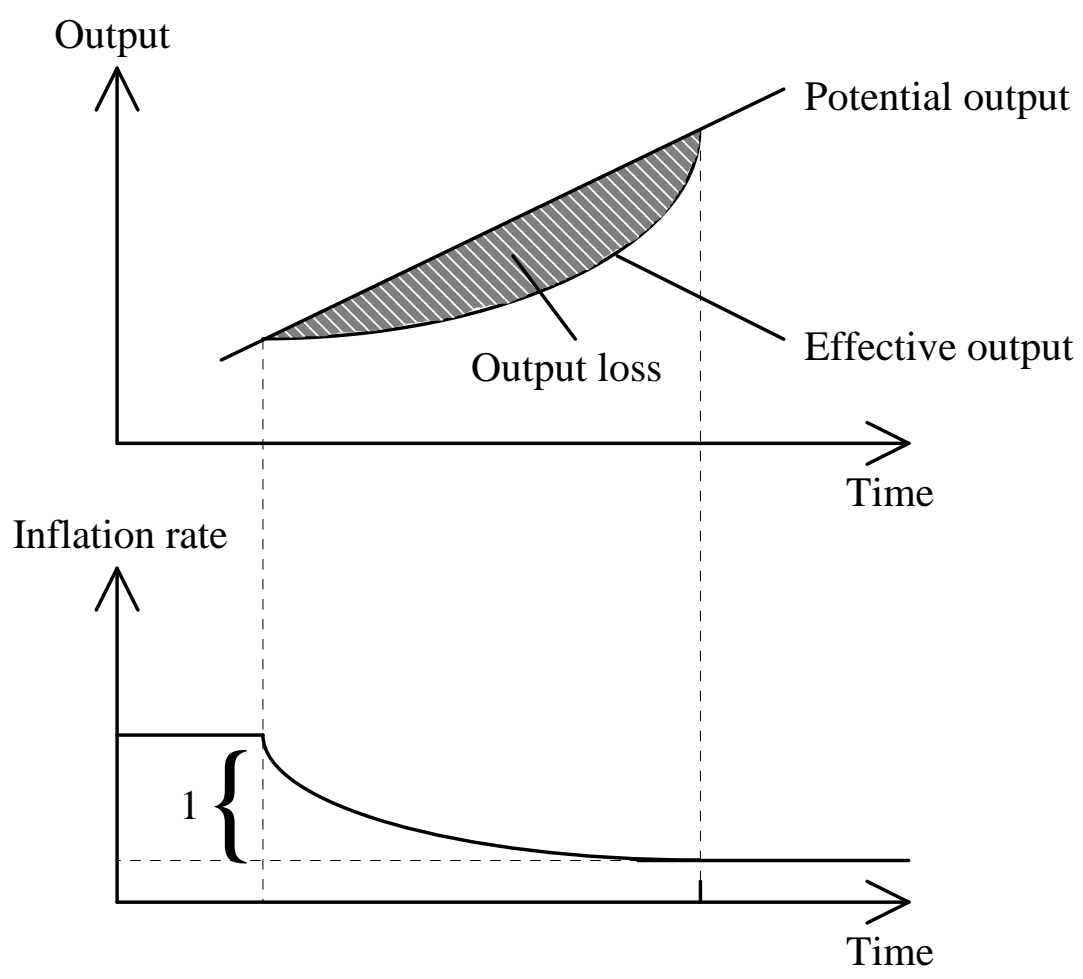

The sacrifice ratio is now widely used in theoretical as well as empirical analyses of real monetary policy effects. It appears to be a useful concept capable of synthesizing complex economic phenomena into a single-digit informative cost measure ${ }^{1}$. Although the sacrifice ratio is a simple concept, its estimation proves however a much more difficult exercise. It requires both identifying changes in monetary policy stance (to enable distinguishing between disinflations and episodes of accelerating inflation) and evaluating their impacts on output and inflation. Several methods have already been proposed and applied.

Early empirical studies (Okun, 1978) are based on the estimation of "Phillips curve" models, which express a relationship between the output gap and inflation variation over a long time series. Okun reports an average sacrifice ratio of $10 \%$ for the United States. In other words, he finds that a permanent one-percentage-point reduction in inflation rate should be associated with a cumulative 10\% loss in real Gross National Product (GNP). Gordon \& King (1982) refine Okun's approach (using 
both traditional and VAR models) to obtain estimates of U.S. sacrifice ratios that range from 0 to 8 , with a mean of about $5 \%$ (less than half of Okun's value). Cuñado \& de Gracia (2003) also use a Phillips curve modelling to estimate individual and common sacrifice ratios for EMU countries over the period 1960-2001. The values of the estimated sacrifice ratios range from 0.55 in Portugal to 1.96 in Finland. They also test the hypothesis that all EMU countries face the same sacrifice ratio and reject this hypothesis over the whole period. Finally, they show that sacrifice ratios take higher values in sub-periods of low inflation rates, suggesting that the Phillips curve is a non-linear function of actual inflation. The paper from Cuñado \& de Gracia (2003) will therefore provide a very interesting comparison with our results for two reasons. Firstly, we will be able to compare the results reached using two alternative methodologies: theirs based on the Phillips curve and ours based on a structural VAR. Secondly, we will provide additional insights regarding the evolution of sacrifice ratios dispersion over time using ten-year rolling estimates, which will provide a useful test for their hypothesis of a non-linear ouput-inflation trade-off.

However, Ball (1994) points out several shortcomings of the Phillips curve approach: the outputinflation trade-off is assumed to remain constant throughout the business cycle (i.e. assumed to be the same during disinflation and accelerating inflation episodes). This approach also constraints the output cost of fighting inflation to be the same for all disinflations during a given time series. These assumptions are not consistent with recent theoretical and empirical macroeconomic insights ${ }^{2}$.

In light of the Phillips curve limitations, Ball (1994) proposes a methodology based on a specific identification of disinflation episodes, obtained by locating "peaks" and "troughs" in the inflation trend (defined as a centred nine-quarter moving average of actual inflation). He then calculates the cumulative output loss (i.e. the sum of output gaps) over each predefined episode, and obtains in this manner an estimate of the sacrifice ratio for each disinflation. These estimates range from below 0 to about $3.5 \%$, with an average close to $1.4 \%$ (i.e. much lower than previous estimates) ${ }^{3}$. Ball's approach to constructing sacrifice ratios has generated many refinements and applications ${ }^{4}$, but this episodespecific method, like early estimates based on Phillips curves, is not devoid of limitations. Cecchetti \& Rich (2001) criticize Ball's approach for assuming each disinflation episode to be generated only by a of Applied Economics, 22 (5), 601-621. DOI : 10.1080/02692170802287672 
monetary policy shift and for neglecting the impact of supply shocks and other demand shocks (such as money demand shocks or fiscal shocks) on the behaviour of inflation and output during these disinflation episodes. The sacrifice ratio estimates could thus be biased, i.e. they could constitute a noisy measure of the effects of monetary contraction. Furthermore, Cecchetti \& Rich (2001) take issue with Okun's (1978) and Gordon \& King's (1982) modelling approach for their incapacity to distinguish between those monetary policy impulses resulting from a true shift in policy and those that simply reflect an endogenous response to changes in the economic situation. This kind of breakdown between exogenous monetary policy shocks and endogenous authority reactions is yet essential in order to correctly evaluate the real effects of disinflation.

That is why Cecchetti \& Rich (2001), relying on Cecchetti (1994), construct sacrifice ratio estimates based on structural VAR models: this approach permits the derivation of a distinction between structural supply shocks and structural demand shocks. Above all, it enables the effects of monetary policy to be broken down into a systematic component and a stochastic component. The former can be considered as a reaction function that describes the responses of the monetary policy authorities to fluctuations in some variables, while the latter contains actions from the central bank that can't be explained by the reaction function (i.e. monetary policy shocks). The aim then is to estimate the impact of these monetary shocks on both output and inflation. In computing cumulative impulse response functions for a given time horizon (presumed to be five years), Cecchetti \& Rich (2001) obtain estimates of U.S. sacrifice ratios over the period 1959-1997 that range from around $1 \%$ to nearly $10 \%$. Their estimates seem to be highly sensitive to the VAR model specification, a conclusion that many other studies using the structural VAR modelling approach have since confirmed.

In our case specifically, this method catches our attention since the aim of this paper is to draw comparisons both across countries and over time. It enables us especially to calculate rolling estimates of the sacrifice ratio in order to better evaluate the evolution of this indicator. of Applied Economics, 22 (5), 601-621. DOI : 10.1080/02692170802287672 


\section{Structural VAR Methodology}

Two procedures for estimating the sacrifice ratio appear to have won favour recently: on the one hand, the methodology introduced by Ball (1994), which entails calculating the output cost of fighting inflation on previously-identified disinflation episodes; and on the other hand, the structural VAR modelling approach in use since Cecchetti (1994).

The choice between these two methods depends on the purpose of the study. Ball's methodology delivers simple and meaningful estimates of the sacrifice ratio, appropriate when isolating inflation and output dynamics during specified disinflation episodes and when analysing the determinants of the output cost of inflation decreases. Nevertheless, it only provides point estimates of the sacrifice ratio, calculated for particular and country-specific disinflations, thereby making it difficult to draw conclusions from sacrifice ratio dynamics or from international comparisons of estimates. Moreover, Ball's methodology doesn't permit the effects of monetary policy shocks to be isolated.

Since the aim of this paper is to study sacrifice ratios dynamics within the euro area over the past thirty years and examine whether the gradual course towards a common monetary policy has triggered a process of convergence in these ratios, Cecchetti's (1994) structural VAR modelling approach would seem to be more appropriate, since it provides an "uninterrupted" estimate of the sacrifice ratio. The potential instability of results depending on model specifications (as reported in many empirical studies) naturally constitutes a drawback to this approach, and this feature will be taken into account by choosing the same model specification for each country within the euro zone. Our analysis thus lies along the same lines as recent empirical studies from Cecchetti (1994), Cecchetti \& Rich (2001), or Boone \& Mojon (1998).

We start with the following bivariate unrestricted Vector Auto Regression (VAR) model: of Applied Economics, 22 (5), 601-621. DOI : 10.1080/02692170802287672 


$$
\left\{\begin{array}{l}
\Delta y_{t}=\sum_{i=1}^{n} \Phi_{11}^{i} \cdot \Delta y_{t-i}+\sum_{i=1}^{n} \Phi_{12}^{i} \cdot \Delta \pi_{t-i}+\mu_{t}^{1} \\
\Delta \pi_{t}=\sum_{i=1}^{n} \Phi_{21}^{i} \cdot \Delta y_{t-i}+\sum_{i=1}^{n} \Phi_{22}^{i} \cdot \Delta \pi_{t-i}+\mu_{t}^{2}
\end{array} \quad t=1, \ldots, T\right.
$$

where $y_{t}$ is the $\log$ of GDP at time $\mathrm{t}, \pi_{t}$ the inflation rate between time $\mathrm{t}-1$ and time $\mathrm{t}$ expressed on an annual basis, and $\mu_{t}=\left[\mu_{t}^{1}, \mu_{t}^{2}\right]^{\prime}$ the vector of innovations, which contains the shocks that affect the vector of endogenous variables $X_{t}=\left[\Delta y_{t}, \Delta \pi_{t}\right]^{\prime}$ at time t.

It is assumed that $\mu_{t} \approx i i d N(0, \Sigma)$, where $\sum$ (variance-covariance matrix of the innovation vector) is a diagonal matrix.

In this unrestricted representation, the innovations $\mu_{t}^{1}$ and $\mu_{t}^{2}$ can't be ascribed any economic interpretation. Since the purpose here is to explicitly evaluate the impact of a demand shock on both inflation and real GDP, we must link the unrestricted VAR model to its underlying structural form.

That's why we seek to estimate the following structural VAR model, as extracted from Cecchetti (1994):

$$
\left\{\begin{array}{l}
\Delta y_{t}=\sum_{i=1}^{n} b_{11}^{i} \cdot \Delta y_{t-i}+b_{12}^{0} \cdot \Delta \pi_{t}+\sum_{i=1}^{n} b_{12}^{i} \cdot \Delta \pi_{t-i}+\varepsilon_{t}^{y} \\
\Delta \pi_{t}=b_{21}^{0} \cdot \Delta y_{t}+\sum_{i=1}^{n} b_{21}^{i} \cdot \Delta y_{t-i}+\sum_{i=1}^{n} b_{22}^{i} \cdot \Delta \pi_{t-i}+\varepsilon_{t}^{\pi}
\end{array} \quad t=1, \ldots, T\right.
$$

where $\varepsilon_{t}=\left[\varepsilon_{t}^{y}, \varepsilon_{t}^{\pi}\right]^{\prime}$ is the vector innovation process, which contains the shocks to aggregate supply $\varepsilon_{t}^{y}$ and aggregate demand $\varepsilon_{t}^{\pi}$. The demand disturbance is assumed to be a monetary shock: this quite restrictive assumption is the natural counterpart of the choice of a simple bivariate VAR model instead of more complicated models, which are found in Cecchetti \& Rich (2001) to generate a very high imprecision in the sacrifice ratio estimates ${ }^{5}$. It is also assumed that $\varepsilon_{t} \approx i i d N(0, \Omega)$, where $\Omega$ (variance-covariance matrix of the vector innovation process) is a diagonal matrix. 
Considering the structural disturbances as exogenous variables and applying Wold's decomposition theorem yields the infinite Vector Moving Average (VMA) representation of the structural model, which will allow us first to compute the system impulse responses to structural shocks and thus to estimate sacrifice ratios:

$$
\left\{\begin{array}{l}
\Delta y_{t}=\sum_{i=0}^{\infty} a_{11}^{i} \cdot \varepsilon_{t-i}^{y}+\sum_{i=0}^{\infty} a_{12}^{i} \cdot \varepsilon_{t-i}^{\pi} \\
\Delta \pi_{t}=\sum_{i=0}^{\infty} a_{21}^{i} \cdot \varepsilon_{t-i}^{y}+\sum_{i=0}^{\infty} a_{22}^{i} \cdot \varepsilon_{t-i}^{\pi}
\end{array} \quad t=1, \ldots, T\right.
$$

In order to move from the reduced model form in (1) to the structural representation (2), a set of identification rules is required. To derive estimates of the effects of structural disturbances $\varepsilon_{t}^{y}$ and $\varepsilon_{t}^{\pi}$, we must assume that the vector of innovations $\mu_{t}$ is a linear combination of the simultaneous structural shocks $\varepsilon_{t}$. Furthermore, the structural shocks are presumed to be uncorrelated and have unit variances, which translates into $\Omega=I$, where $I$ is the identity matrix. To complete the identification of the structural VAR model, we must adopt additional assumptions regarding the value of $n .(n-1) / 2$ parameters (where $\mathrm{n}$ is the number of endogenous variables). In our case, $\mathrm{n}=2$; we thus need one "identifying restriction", which can be taken from economic theory.

Following Blanchard \& Quah's (1989) empirical work as well as Cecchetti \& Rich's (2001) estimates of sacrifice ratios, our additional identifying restriction is that aggregate demand shocks (denoted as $\varepsilon_{t}^{\pi}$ up until now) have no permanent effect on the level of real GDP, unlike aggregate supply shocks $\left(\varepsilon_{t}^{y}\right)$. In other words, the cumulative long-run effect of a demand shock on real GDP is assumed to be zero. Going back to the VMA representation from our structural VAR model (3), the long-run identifying restriction can then be written as:

$$
\sum_{i=0}^{\infty} a_{12}^{i}=0
$$

We are aware that long-run neutrality of money is a questionable hypothesis: several theoretical as well as empirical papers focusing on the euro area have shown recently that monetary policy should 
have an effect on potential output due to "hysteresis" effects ${ }^{6}$. That is why we also try an alternative identifying assumption to distinguish between the supply and demand shocks: we assume that demand shocks do not have an instantaneous effect on inflation, unlike supply shocks. In other words, the contemporaneous effect of a demand shock on inflation is assumed to be zero ${ }^{7}$. This short-run identifying restriction translates into:

$$
a_{22}^{0}=0
$$

Under the (quite restrictive) assumption that the aggregate demand shocks identified in the structural VAR correspond to shifts in the stance of monetary policy, an estimate of the sacrifice ratio can be obtained rather easily using the VMA representation (3). Computing the impulse response functions yields estimates of parameters $a_{11}^{i}, a_{12}^{i}, a_{21}^{i}$ and $a_{22}^{i}$. These coefficients will allow us to calculate the sacrifice ratio $S(\tau)$ over a given time horizon $\tau$.

The denominator of this ratio is the cumulative final effect of a monetary policy shock $\varepsilon_{t}^{\pi}$ undertaken at time $\mathrm{t}$ on the inflation rate level at time $\mathrm{t}+\tau$, while the numerator of the sacrifice ratio would be defined as the cumulative output loss between times $\mathrm{t}$ and $\mathrm{t}+\tau$ following the same monetary shock $\varepsilon_{t}^{\pi}$ : it is not just the cumulative effect of this disturbance on the real GDP level at time $t+\tau$, but the sum of its effects through the first $\tau$ periods as well. The sacrifice ratio can thus ultimately be written as a function of the time horizon $\tau$, and computed as follows:

$$
S(\tau)=\frac{\sum_{j=0}^{\tau}\left(\delta y_{t+j} / \delta \varepsilon_{t}^{\pi}\right)}{\left(\delta \pi_{t+\tau} / \delta \varepsilon_{t}^{\pi}\right)}=\frac{\sum_{i=0}^{\tau}\left(\sum_{j=0}^{i} a_{12}^{i}\right)}{\sum_{i=0}^{\tau} a_{22}^{i}}
$$

This statistical definition perfectly matches the literal one given previously: the sacrifice ratio can in fact be seen as the cumulative impact on GDP level from a monetary policy shock that would eventually reduce inflation by one percentage point between times $t$ and $t+\tau$. 


\section{Empirical Results}

\subsection{Preliminary Data Analysis}

The purpose of this paper is to estimate a sacrifice ratio for each of the twelve EMU countries over the period 1972:1-2003:4, which would allow us to evaluate the degree of structural dispersion among these countries. We use quarterly data on real Gross Domestic Product (GDP) and inflation rate, defined as the annual growth rate of the Consumer Price Index (CPI). GDP data have been converted into logarithms (and denoted LGDP). Appendix A1 describes these data in further details.

A preliminary stationarity analysis of the series (correlograms, Augmented Dickey-Fuller (ADF) and Phillips-Perron tests) suggests that real GDP and inflation rate are both I(1) processes (i.e. real GDP and inflation rate both contain a unit root) in each of our twelve countries. In other words, it appears that neither of the two series is stationary. This finding provides support for the definition of sacrifice ratio as well as for our model specification. The denominator of the sacrifice ratio does in fact correspond to the cumulative effect of a monetary shock on the inflation rate: in order to avoid a zero denominator, deviations in the inflation rate from its initial level must be permanent (i.e. not just transitory). Moreover, our long-run identifying restriction requires non-stationarity of the real GDP series, since we are assuming that the aggregate supply shock exerts a permanent impact on the output path. Lastly, real GDP and inflation are assumed to contain a unit root within our specification model; this assumption perfectly suits our data.

That's why our structural VAR models are constructed with both the quarterly change in the log of real GDP (first difference of log real GDP, denoted DLGDP) and the quarterly change in annual inflation rate (first difference of annual inflation rate, denoted DINF).

\subsection{Sacrifice Ratios Computations and Sub-Period Analyses}

The first step in our estimation procedure entails choosing the optimal lag length in each country's VAR model; this lag length must be sufficient to generate a vector of white-noise innovations, yet must not be too high with respect to our sample length (only 128 quarters in each country). For this choice, we make use of both information criteria (Akaike and Schwarz criteria) and likelihood ratio of Applied Economics, 22 (5), 601-621. DOI : 10.1080/02692170802287672 
tests (starting with a maximum of 12 lags and then testing whether or not the last lag is significant). The various criteria suggest that four lags are to be taken for each of the twelve countries, which would seem reasonable given the sample length and data frequency. This result also appears to be consistent with the theoretical lags in the influence of monetary policy on output and prices ${ }^{8}$.

Another preliminary remark must be forwarded before turning our attention to the calculation of sacrifice ratios: in order to take into account the effects of German reunification, a dummy variable is introduced in the German system over the period 1991:1-1991:4. We have also added exogenous variables in order to take into account the influence of the external environment. More precisely, we use two exogenous variables: the change in the U.S. dollar price of oil and the change in the nominal exchange rate versus the dollar (e.g. in the French VAR model, we have used the franc/dollar exchange rate until 1999, and the euro/dollar exchange rate since then).

The second step in our estimation procedure consists of computing the impulse response functions of the system to both a supply shock and a demand shock. The impulse response functions reached using the long-run identifying restriction are reported in Appendix $\mathrm{A} 2^{9}$.

Aggregate supply shocks carry the series of GDP growth and inflation variation in opposite directions over the short run. Moreover, the cumulative impulse response functions show that the effect of such a shock on real output is permanent, while the effect on the inflation rate varies depending on the country: for some countries (Austria, France, Germany, Greece, Luxembourg and the Netherlands) the cumulative effect may prove to be permanent and negative, while for others (Belgium, Finland, Ireland, Italy, Portugal and Spain) it may be a transitory negative effect offset thereafter by an inflation acceleration linked to the simultaneous output growth acceleration.

As for aggregate demand shocks, presumed to be monetary policy shocks, our identifying restriction precludes any long-run effects of such disturbances on real GDP. Besides, aggregate demand shocks have permanent effects on the inflation rate. On the whole, the impact of monetary policy shocks on the output path and inflation seems to be consistent with our definition of a sacrifice ratio. of Applied Economics, 22 (5), 601-621. DOI : 10.1080/02692170802287672 
The last step in our procedure then calls for calculating sacrifice ratios using the empirical methodology explained in Section 3. Table 1 presents the estimates of these sacrifice ratios for a time horizon set at five years in each EMU member country, when the long-run identifying restriction suggested in Blanchard \& Quah (1989) is employed.

Table 1. Sacrifice ratios in the euro area over the whole period (for a time horizon set to 5 years)

\begin{tabular}{cc}
\hline \hline & $\mathbf{1 9 7 2 : 1 - 2 0 0 3 : 4}$ \\
\hline \hline Austria & 0,50014 \\
Belgium & $-0,02035$ \\
Finland & 0,22811 \\
France & 0,46404 \\
Germany & 0,75666 \\
Greece & 0,6095 \\
Ireland & 0,63086 \\
Italy & 0,46701 \\
Luxembourg & 2,06767 \\
Netherlands & 0,35528 \\
Portugal & 0,396 \\
Spain & 0,35907 \\
\hline \hline Average & 0,5678 \\
Standard deviation & 0,5131 \\
\hline \hline
\end{tabular}

Table 1 first reveals that the sacrifice ratio estimates are positive over the entire period 1972-2003 in each country (except for Belgium), which indicates the presence of a short-run trade-off between output and inflation. It may be observed that the structural VAR methodology employed in this paper, unlike Ball's (1994) episode-specific technique, leads to estimates of a linear combination of a true sacrifice ratio during disinflations and a "benefit ratio" (according to Cecchetti, 1994) during accelerating inflation episodes. The information content from episodes during which inflation and output increase following a positive monetary policy shock is indeed as useful as any disinflation episode can be ${ }^{10}$.

Moreover, our estimates of European sacrifice ratios are, on average, lower than those derived by Cecchetti \& Rich (2001) for the U.S. using the same model specification. For example, our computations suggest that a one-percentage-point permanent reduction in the yearly inflation rate 
entails a $0.46 \%$ cumulative output loss in France, over a five-year time horizon. Our results are however very close to those reached by Cuñado \& de Gracia (2003) with a Phillips Curve approach over the extended period 1960-2001.

The sacrifice ratio estimates seem reasonably similar across euro area countries over the whole sample period. In eight of the twelve cases, the sacrifice ratio lies within a range between 0.35 and $0.63 \%$. Only Germany and Luxembourg have higher sacrifice ratios, while Finland and Belgium exhibit lower values (almost zero, yet negative in the case of Belgium).

Lastly, we can compare these results with those reached using bivariate structural VAR models with the short-run identifying restriction to evaluate the robustness of our results to the specification of the model. Results are reported in Appendix A3. It appears that the estimates of EMU sacrifice ratios are somewhat higher when the short-run constraint is employed, which is perfectly consistent since the cumulative effect of the monetary shock on the GDP level is not compelled to be nil in the long-run any more.

A sub-period analysis however shows considerable variability in sacrifice ratios both over time and across countries. The whole period has been split here into two sub-periods corresponding to dissimilar economic conditions. The first one (1972:1-1993:4) exhibits sizeable fluctuations in inflation rates during a high inflation regime: there is an inflation acceleration following the oil price shocks of 1973 and 1979, and then a fast disinflation. The second sub-period (1994:1-2003:4) pertains to a low inflation-variability period, with slow disinflation during a low inflation regime, which illustrates the effects of the Maastricht Treaty and the move towards the EMU. Figures 2 and 3 display these striking trends in the average euro area inflation rate and national inflation rates dispersion over the period 1972-2003. 
Figure 2. Average inflation rate within the euro area over the period 1972-2003

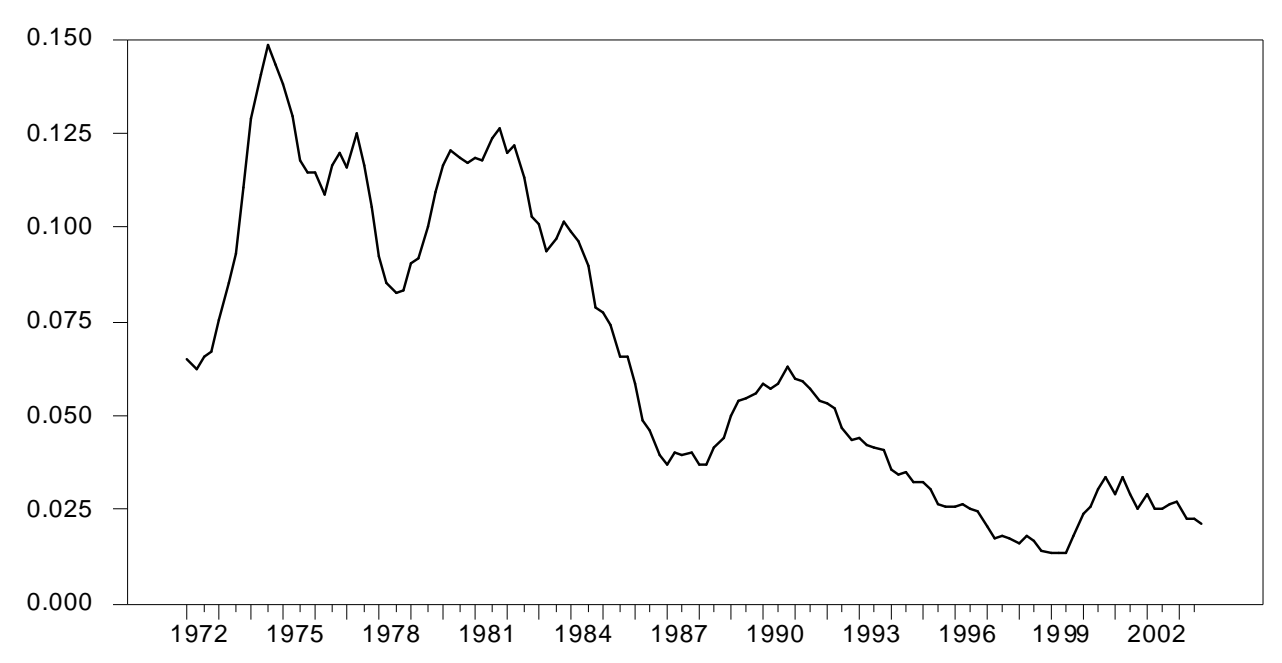

Figure 3. Standard deviation among euro area national inflation rates between 1972 and 2003

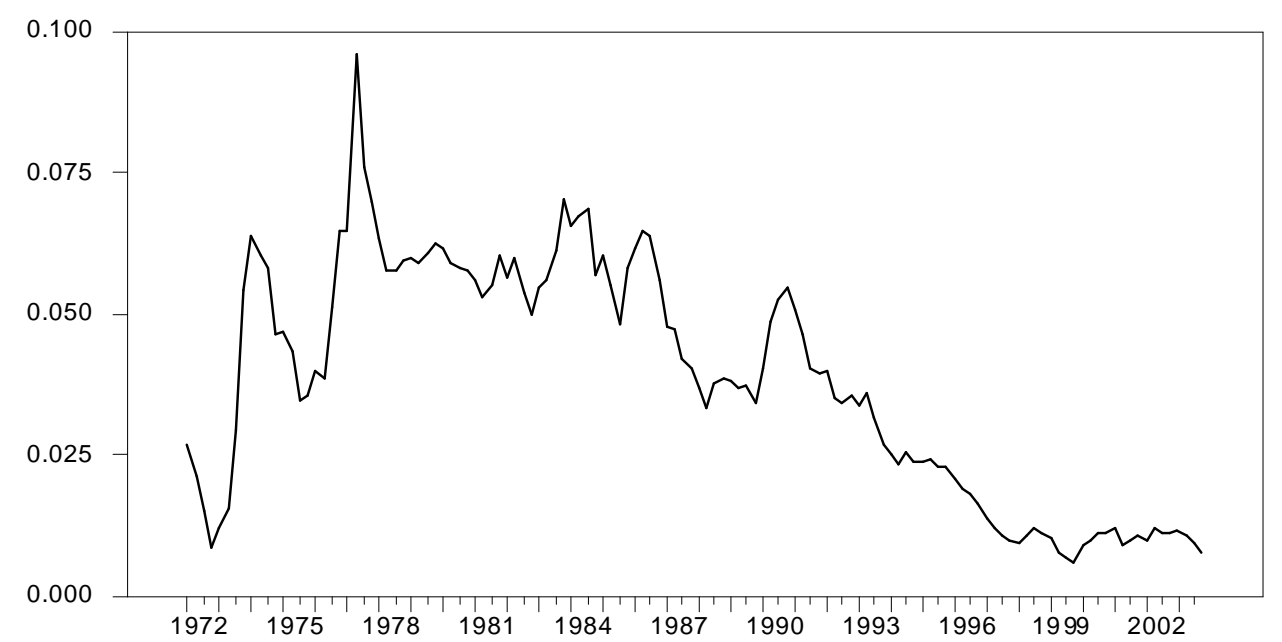

Table 2 provides evidence on significant differences in the sacrifice ratio estimates over the two subperiods. On average, sacrifice ratios are much higher during the second sub-period (1994-2003) than during the first (1972-1993), while inflation rates clearly decrease. This finding would suggest the existence of a negative relationship between the average level of inflation and the output cost of disinflation: this relationship has been emphasized in many early studies, such as Ball (1994), Andersen \& Wascher (1999) and Cuñado \& de Gracia (2003). This observation is also consistent with the results reached using the short-run identifying restriction, displayed in Appendix A3. We will focus specifically on this point in the subsequent discussion. 
Sub-period estimates also show quite considerable differences in sacrifice ratios among European countries, and the standard deviation associated with sacrifice ratios estimates clearly increases from the first sub-period to the second.

Nevertheless, it must be noted that two out of the twelve countries exhibit negative sacrifice ratios over each sub-period (yet often very close to zero). This result is rather disturbing and suggests that disinflation can imply a gain in output or, conversely, that an increase in inflation rate can involve an output loss.

Table 2. Sacrifice ratios in the euro area over the sub-periods (for a time horizon set to 5 years)

\begin{tabular}{ccc}
\hline \hline & $\mathbf{1 9 7 2 : 1 - 1 9 9 3 : 4}$ & $\mathbf{1 9 9 4 : 1 - 2 0 0 3 : 4}$ \\
\hline \hline Austria & 0,26187 & 2,31753 \\
Belgium & $-0,13056$ & 0,40801 \\
Finland & $-0,00832$ & 0,35287 \\
France & 0,5226 & 1,30708 \\
Germany & 0,98923 & 0,92066 \\
Greece & 0,60499 & $-0,38867$ \\
Ireland & 0,57673 & $-0,00542$ \\
Italy & 0,43662 & 0,37499 \\
Luxembourg & 1,60656 & 4,37024 \\
Netherlands & 0,25109 & 3,20054 \\
Portugal & 0,01349 & 0,89562 \\
Spain & 0,21989 & 0,8984 \\
\hline \hline Average & 0,4453 & 1,2210 \\
Standard deviation & 0,4805 & 1,4004 \\
\hline \hline
\end{tabular}

Finally, the calculation of standard deviations across European sacrifice ratios over sub-periods cannot provide evidence of a convergence process within the euro area. In order to analyse with greater precision the dynamics of sacrifice ratio dispersion within this area, we construct ten-year rolling estimates over the period 1972-2003.

\subsection{Rolling Estimates of the Sacrifice Ratio}

The first step in this procedure is to estimate a sacrifice ratio for each country over each ten-year subperiod. The first estimate refers to the period 1972:1-1981:4, and the sacrifice ratio obtained using our 
bivariate VAR model with the long-run identifying restriction ${ }^{11}$ for a five-year horizon is given at the date 1981:4. Similarly, the result for the date 1982:1 consists of the sacrifice ratio estimate over the period 1972:2-1982:1. We proceed in this way until the period 1994:1-2003:4, with the result reported in 2003:4. A measurement of the sacrifice ratio is therefore obtained for each quarter over the period 1981:4-2003:4.

The second step then seeks to evaluate the sigma-convergence ( $\sigma$-convergence) process using the standard deviation of sacrifice ratios across countries as a dispersion indicator. This step leads us to computing the average euro area sacrifice ratio and the standard deviation across European countries for each quarter over the period 1981:4-2003:4. Figure 4 displays the trends in these two indicators within the EMU.

Figure 4. Average and standard deviation of European sacrifice ratios, obtained using ten-year rolling estimates

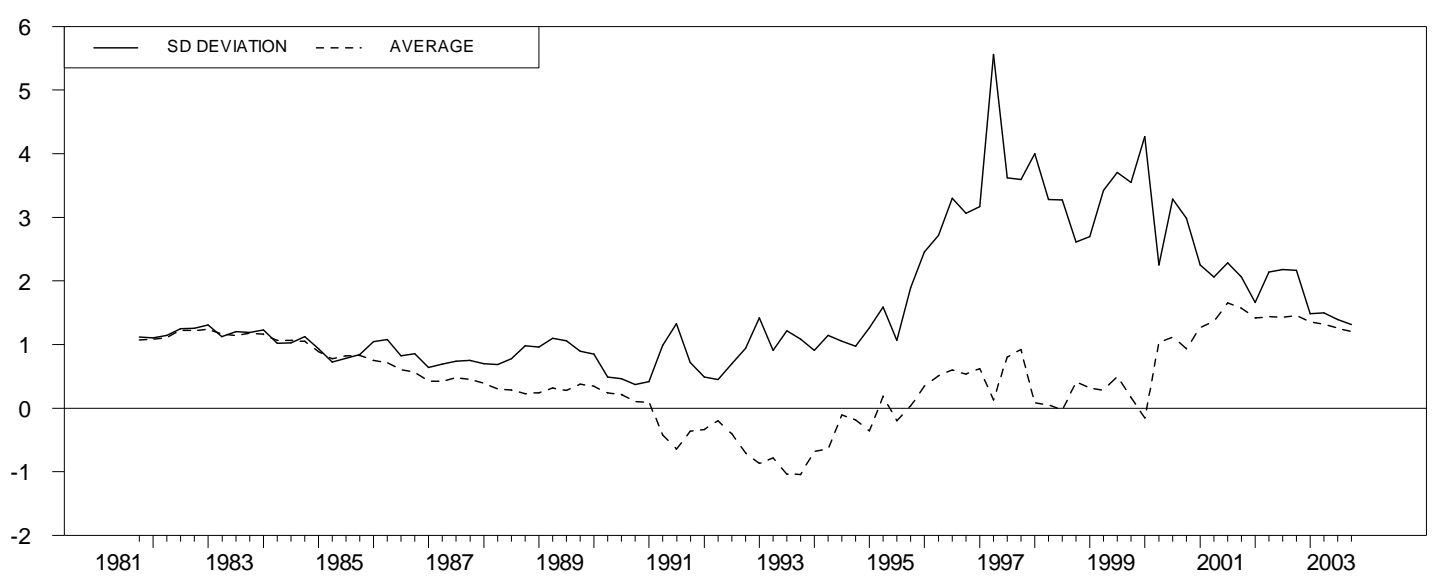

A detailed analysis of these trends would appear to entail two main findings.

Conclusion 1: A recent increase in the euro area average sacrifice ratio.

Figure 4 confirms and refines the trend in the average sacrifice ratio suggested by means of sub-period analysis: this average ratio decreases until 1993, moving from 1.0 in 1981:4 (an estimate over the period 1972:1-1981:4) to -0.80 in 1993:2 (an estimate over the period 1983:3-1993:2), and tends to increase since. 
The fall in the average sacrifice ratio observed until 1993 may be tied to people's inflation expectations and central bank credibility, two factors identified by Fuhrer (1995) as key determiners of the output cost of fighting inflation. In the beginning of the eighties, European national central banks entered into a disinflation process with a low degree of credibility, which slowed inflation adjustments: the impetus remained oriented around asking for high nominal wage increases in order to maintain the same real wages. Lucas (1973) and Sargent (1983) show that such behaviour generates high inflation persistence and therefore huge output costs of disinflation policies. Being committed to and then succeeding in curbing inflation, central banks invested in credibility, and inflation expectations were gradually adjusted. As a result, disinflation proved to be less and less costly, which translated into a decrease in the sacrifice ratio.

However, once the monetary authorities had acquired substantial credibility and inflation seemed on the way to being curbed (as appeared to be the case in 1993 in almost all European countries), we may properly assume that a switch in the key determinants of sacrifice ratio has taken place: the inflation level appears to have driven the output cost of disinflations since then, as theoretical and empirical studies such as Ball et al. (1988) or Akerlof et al. (1996) suggest. When the initial inflation level is already rather low, a reduction in the inflation rate by an additional one percentage point becomes increasingly costly, given that inflation persistence increases (especially because firms lengthen the period between price adjustments, wage indexation tends to be rare, and the duration of wage and other contracts increases). The rise in euro area sacrifice ratios since 1993 most probably stems from this phenomenon.

\section{Conclusion 2: No evidence for the convergence of euro area sacrifice ratios.}

The trend in the standard deviation across EMU sacrifice ratios does not indicate a reduction in their dispersion: no evidence of a $\sigma$-convergence process at work can be identified ${ }^{12}$.

Nevertheless, the decade from 1993 to 2003 has seen strong nominal convergence enforced by the Maastricht Treaty criteria: the adjustment of national inflation rates in fact constituted a prerequisite to participation in the EMU launched in 1999. This actually translated into a narrowing of the gap between national inflation rates over the period 1993-1999, as indicated in Figure 3. As a result, the of Applied Economics, 22 (5), 601-621. DOI : 10.1080/02692170802287672 
divergence of sacrifice ratios among EMU countries observed since 1993 cannot be explained by inflation differentials, nor can it stem from huge differences in the credibility of monetary authorities, particularly since 1999 (i.e. since the creation of the ECB). Consequently, persistent differences in the output cost of fighting inflation could certainly be explained by structural disparities, especially differences in wage and price rigidities on European markets.

\section{Conclusions}

Computing sacrifice ratios for the twelve euro area countries and analysing their dynamics over the period 1972:1-2003:4 would suggest two main conclusions.

First, the level of inflation seems to play nowadays an essential role in the output cost of fighting inflation: the sacrifice ratio appears to be particularly high within a low-inflation environment. This result is perfectly in line with the findings reached in recent theoretical and empirical studies (Ball et al., 1988; Ball, 1994; Akerlof et al., 1996; Andersen and Wascher, 1999; Cuñado and de Gracia, 2003; Zhang, 2005). It also proves to be quite a robust result despite the instability in sacrifice ratio estimates. Besides, the negative relationship between the inflation level and the value of the sacrifice ratio in conditions of low inflation can be seen as another justification for the clarification of the ECB's monetary policy strategy that was announced in May 2003: the ECB's Governing Council made clear that, in the pursuit of price stability, it aims to "maintain inflation rates below, but close to, $2 \%$ over the medium term" (European Central Bank, 2003, p. 79). This clarification appeared as an explicit recognition of the risks and costs associated with a zero inflation target. The ECB identified four potential arguments for tolerating small positive inflation rates: the risk of deflation, the possibility of an upward measurement bias in the inflation rate, the presence of downward nominal rigidities in prices and wages ${ }^{13}$, and finally the existence of structural inflation differentials. Our results provide an additional argument for small positive inflation rates, since they indicate that an objective of perfect price stability should give rise to huge output $\operatorname{costs}^{14}$.

Second, our results suggest that the nominal convergence observed since 1993 did not trigger a true convergence process of European sacrifice ratios. Following Boone \& Mojon (1998), i.e. using the comparison of these sacrifice ratios as an indicator for structural proximity, we cannot provide of Applied Economics, 22 (5), 601-621. DOI : 10.1080/02692170802287672 
evidence of a reduction in structural differences among EMU countries. More precisely, differences in European sacrifice ratios could partly come from differences in European goods and labour markets. Many empirical studies, such as Ball (1994), show that wage rigidity is an essential determinant of the sacrifice ratio. Recent macroeconomic comparisons of European countries precisely emphasize remaining differences in nominal wage rigidities, resulting from disparities in wage-setting institutions (frequency of wages adjustment, degree of indexation, synchronisation of adjustment across sectors). These disparities may still remain for a long time, implying persistent differences in European sacrifice ratios. Such differences are likely to raise an important issue within the single monetary policy framework, since they imply that the same monetary impulse should entail various reactions from one country to another.

Nevertheless, our results do not allow for a quantification of the relationship between labour market rigidities and the output cost of fighting inflation. Future research should try to assess with more precision the influence of remaining disparities between European labour markets in the dispersion of sacrifice ratios. 


\section{Appendix A1: Description and Preliminary Analysis of the Data}

We construct sacrifice ratios estimates from structural VAR models using quarterly inflation and output data for the twelve EMU countries over the sample period 1972:1-2003:4. Inflation is measured by the annual growth rate of the Consumer Price Index (CPI). For output, we use real Gross Domestic Product (GDP), in 1995 U.S. dollars expressed in Purchasing Power Parity (PPP). These series are extracted from the OECD Economic Outlook

A preliminary stationarity analysis of the series is essential. Standard stationarity tests are implemented: Augmented Dickey-Fuller (ADF) tests (introduced in Dickey \& Fuller, 1981), and Phillips-Perron tests (Phillips \& Perron, 1988). For each country within the euro area, the series of real GDP and inflation rates prove to be non-stationary (i.e. variables contain a unit root). These findings are indeed consistent with our model specification: the first differences of real GDP and inflation rate can be introduced into our VAR model, which requires stationary variables.

Since we have shown that both real GDP and inflation rate contain a unit root, we must also check that these two series do not cointegrate. In order to grasp the cointegration hypothesis, we employ the methodology and tests proposed in Engle \& Granger (1987). Computation of the CRDW (Cointegration Regression Durbin Watson) statistic associated with the cointegration relation, as well as the use of ADF tests on the series of estimated residuals, leads to the same result in each of twelve euro area countries: we cannot reject the null hypothesis of non-stationarity. In the end, real GDP and the inflation rate clearly do not cointegrate. We can note that this finding reinforces the key identifying restriction from our structural VAR model, which implies that monetary policy shocks do not exert permanent long-run effects on the real GDP level. 
Appendix A2: Cumulative Impulse Response Functions of Bivariate Structural VAR

Models over the Period 1972-2003
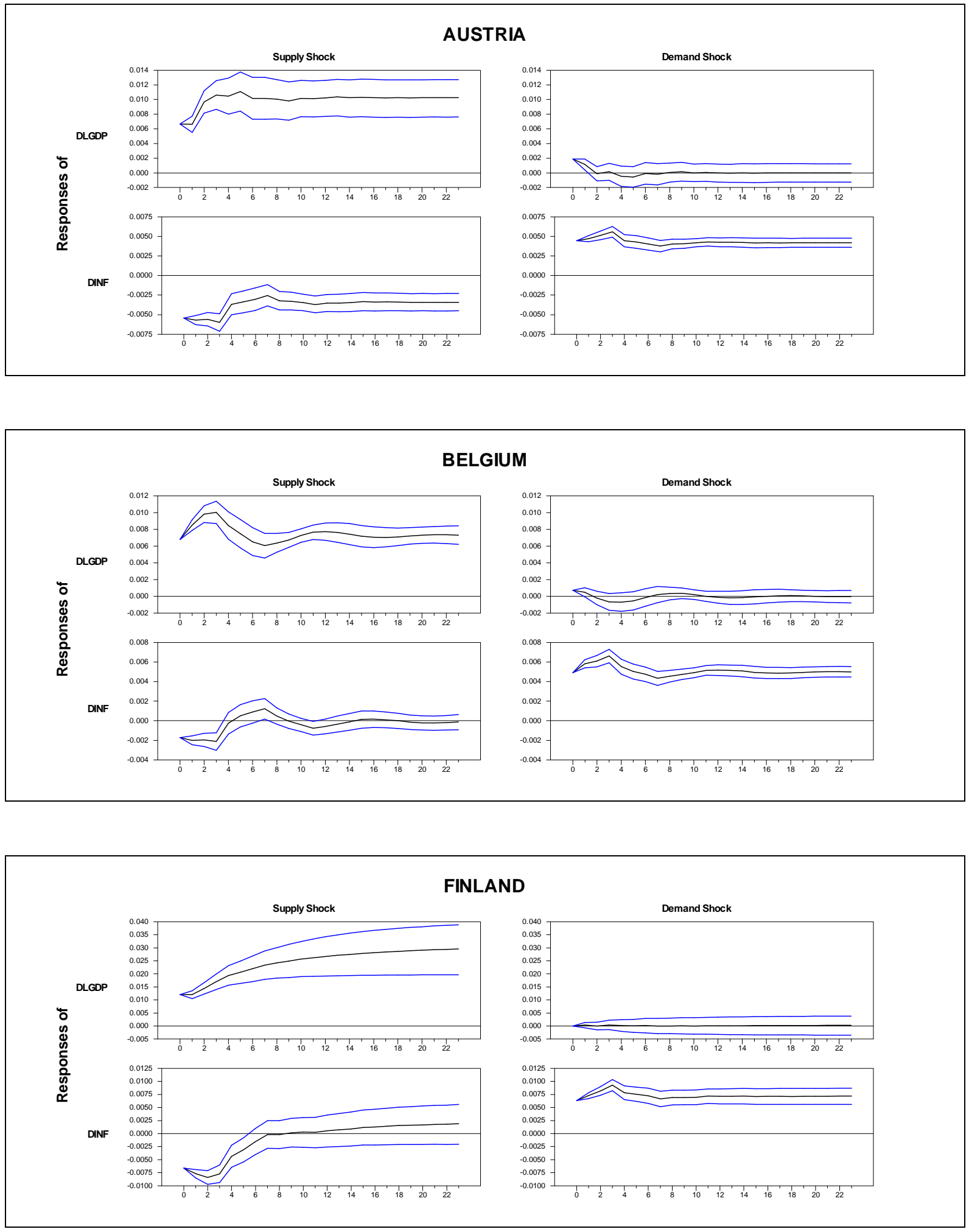

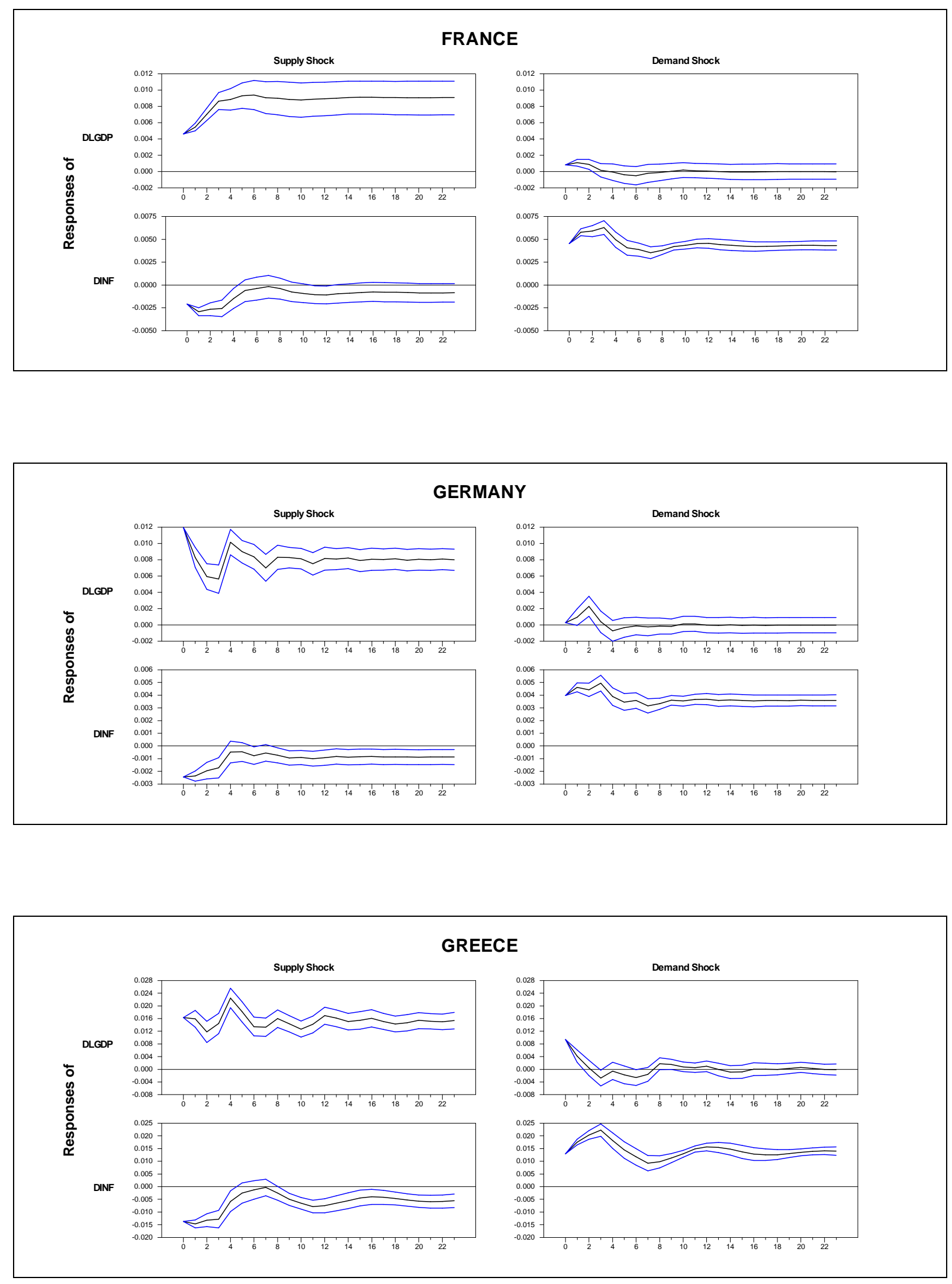

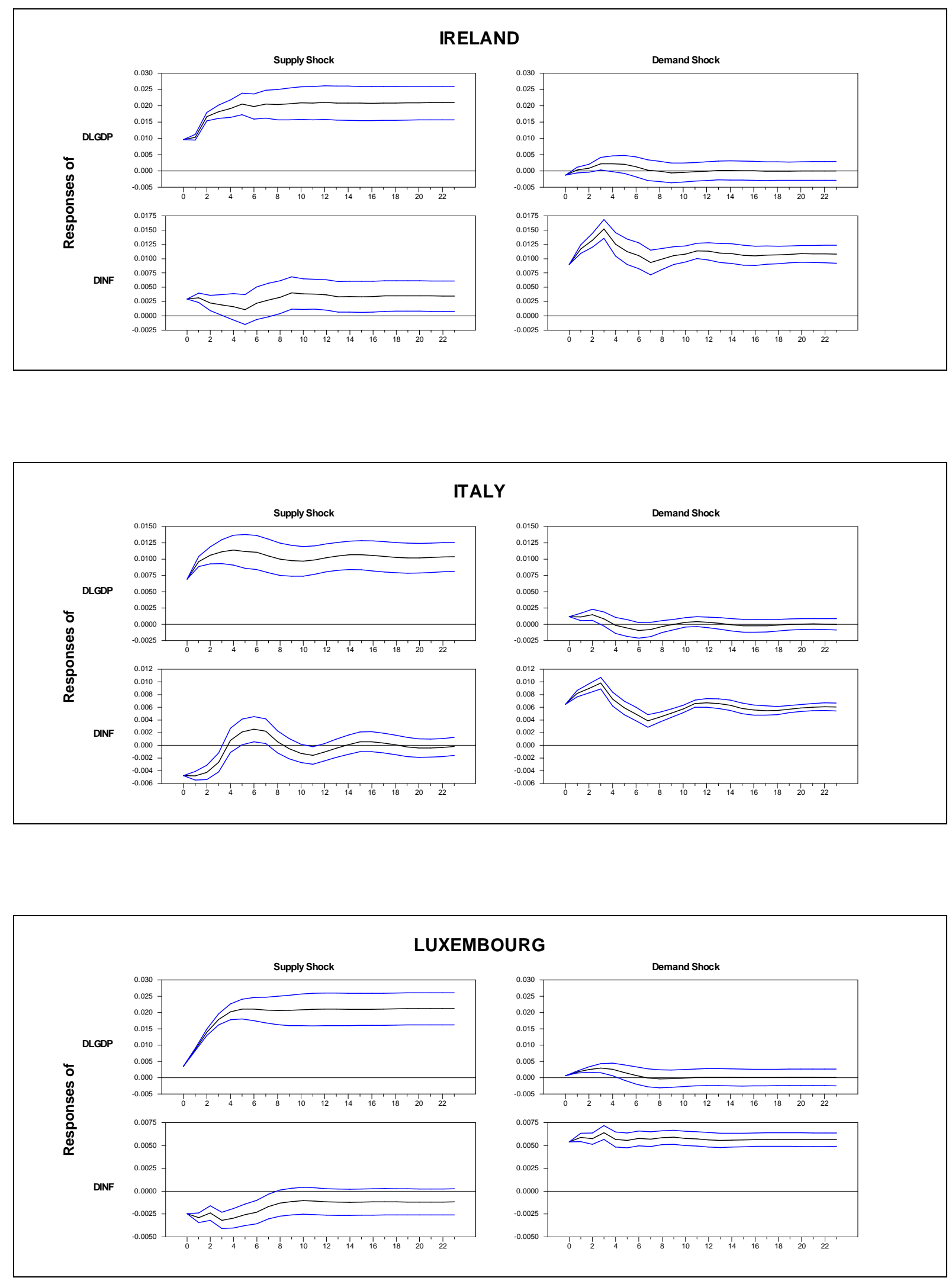

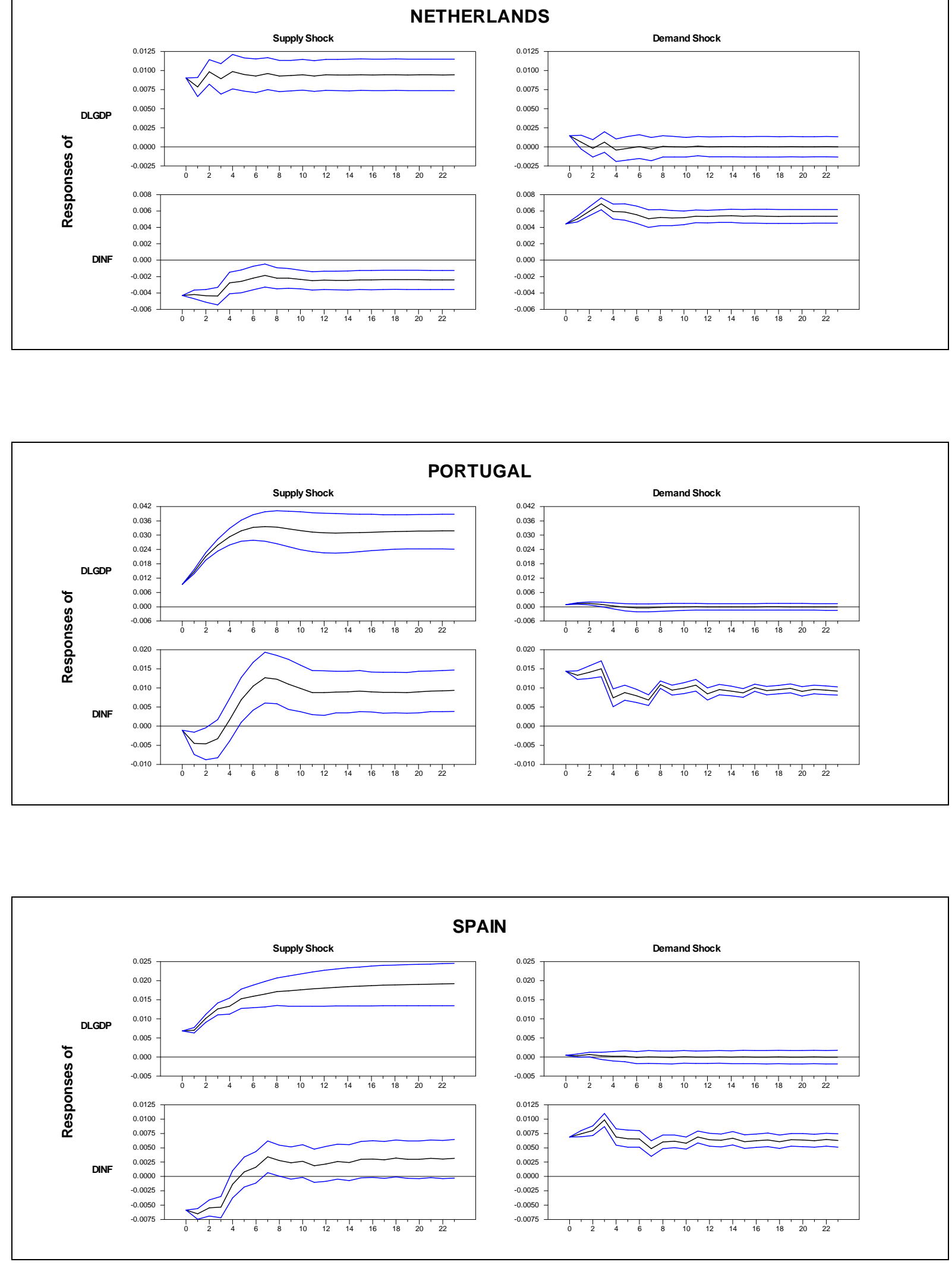
Appendix A3: Results with a short-run identifying restriction in our bivariate SVAR

\begin{tabular}{cccc}
\hline \hline & $\mathbf{1 9 7 2 : 1 - 2 0 0 3 : 4}$ & $\mathbf{1 9 7 2 : 1 - 1 9 9 3 : 4}$ & $\mathbf{1 9 9 4 : 1 - 2 0 0 3 : 4}$ \\
\hline \hline Austria & 1,19266 & 1,06486 & 4,16593 \\
Belgium & 0,94466 & 0,64578 & $-1,78837$ \\
Finland & 0,53685 & 0,50535 & 2,38611 \\
France & 1,49168 & 1,36303 & 2,33001 \\
Germany & 1,23477 & 1,11272 & $-2,29423$ \\
Greece & 0,37302 & 0,38398 & 7,67982 \\
Ireland & 0,811838 & $-7,94239$ & 9,93875 \\
Italy & 0,52069 & 0,55895 & 0,66125 \\
Luxembourg & 2,8273 & 1,0876 & 1,3602 \\
Netherlands & 0,67632 & 0,5465 & $-3,26618$ \\
Portugal & 4,93517 & 6,43298 & 2,05215 \\
Spain & 0,38437 & 0,3352 & 0,78658 \\
\hline \hline Average & 1,3274 & 0,5079 & 2,0010 \\
Standard deviation & 1,3222 & 3,1381 & 3,8663 \\
\hline \hline
\end{tabular}




\section{References}

Akerlof, G.A., Dickens, W.T. \& Perry, G.L. (1996) The Macroeconomics of Low Inflation, Brookings Papers on Economic Activity, 1, pp. 1-59.

Akerlof, G.A., Dickens, W.T. \& Perry, G.L. (2000) Near-Rational Wage and Price Setting and the Long-Run Phillips Curve, Brookings Papers on Economic Activity, 1, pp. 1-44.

Andersen, P.S. \& Wascher, W.L. (1999) Sacrifice Ratios and the Conduct of Monetary Policy in Conditions of Low Inflation, BIS Working Paper 82.

Ball, L. (1994) What Determines the Sacrifice Ratio?, in: N.G. Mankiw (Ed.), Monetary Policy, pp. 155-182 (Chicago, Chicago University Press).

Ball, L. (1999) Aggregate Demand and Long-Run Unemployment, Brookings Papers on Economic Activity, 2, pp. 189-251.

Ball, L., \& Mankiw, N.G. (2002) The NAIRU in Theory and Practice, Journal of Economic Perspectives, 16 (4), pp. 115-136.

Ball, L., Mankiw, N.G. \& Romer, D. (1988) The New Keynesian Economics and the Output-Inflation Trade-off, Brookings Papers on Economic Activity, 1, pp. 1-65.

Blanchard, O.J. \& Quah, D. (1989) The Dynamic Effects of Aggregate Demand and Supply Disturbances, American Economic Review, 79 (4), pp. 655-673.

Boone, L. \& Mojon, B. (1998) Sacrifice Ratios in Europe: a Comparison, CEPII Working Paper 07.

Cecchetti, S.G. (1994) Comment, in: N. G. Mankiw (Ed.), Monetary Policy, pp. 188-193 (Chicago, Chicago University Press).

Cecchetti, S.G. \& Rich, R.W. (2001) Structural Estimates of the U.S. Sacrifice Ratio, Journal of Business and Economic Statistics, 19 (4), pp. 416-427.

Cuñado, J. \& de Gracia, F.P. (2003) Sacrifice Ratios: Some Lessons from EMU Countries, 1960-2001, International Review of Applied Economics, 17(3), pp. 327-337.

Dickey, D.A. \& Fuller, W.A. (1981) Likelihood Ratio Statistics for Autoregressive Time Series with a Unit Root, Econometrica, 49 (4), pp. 1057-1072. 
Engle, R.F. \& Granger, C.W.J. (1987) Cointegration and Error Correction: Representation, Estimation and Testing, Econometrica, 55 (2), pp. 251-276.

European Central Bank (2003) The Outcome of the ECB's Evaluation of its Monetary Policy Strategy, Monthly Bulletin, June, pp. 79-92.

Filardo, A.J. (1998) New Evidence on the Output Cost of Fighting Inflation, Federal Reserve Bank of Kansas City Economic Review, 83 (3), pp. 33-61.

Fuhrer, J.C. (1995) The Persistence of Inflation and the Cost of Disinflation, New England Economic Review, January/February, pp. 3-16.

Gordon, R.J. \& King, S.R. (1982) The Output Cost of Disinflation in Traditional and Vector Autoregressive Models, Brookings Papers on Economic Activity, 1, pp. 205-242.

Jordan, T.J. (1997) Disinflation Costs, Accelerating Inflation Gains and Central Bank Independence, Review of World Economics /Weltwirtschaftliches Archiv, 133 (1), pp. 1-21.

Logeay, C. \& Tober, S. (2006) Hysteresis and the Nairu in the Euro Area, Scottish Journal of Political Economy, 53 (4), pp. 409-429.

Lucas, R.E. (1973) Some International Evidence on Output-Inflation Tradeoffs, American Economic Review, 63 (3), pp. 326-334.

Neely, C.J. \& Waller, C.J. (1997) A Benefit-Cost Analysis of Disinflation, Contemporary Economic Review, 15 (1), pp. 50-64.

Okun, A.M. (1978) Efficient Disinflationary Policies, American Economic Review, 68 (2), pp. 348352.

Phillips, P.C.B. \& Perron, P. (1988) Testing for a Unit Root in Time Series Regression, Biometrika, 75, pp. 335-346.

Sargent, T.J. (1983) Stopping Moderate Inflations: the Methods of Poincaré and Thatcher, in: R. Dornbusch and M.H. Simonsen (Eds.), Inflation, Debt and Indexation (Cambridge, Mass.: MIT Press).

Zhang, L.H. (2005) Sacrifice Ratios with Long-Lived Effects, International Finance, 8 (2), pp. 231262. 


\section{Notes}

We are indebted to two anonymous referees for insightful comments. We also wish to thank the participants at seminars at the $22^{\text {nd }}$ Symposium on Banking and Monetary Economics (France, Strasbourg, June 2005) for helpful comments on a earlier version of this paper.

${ }^{1}$ Two key comments need to be made regarding the definition of a sacrifice ratio. First, this ratio is not a measure of the net cost of disinflation: it does not take into account the long-term benefits associated with lower inflation. Second, the output cost is only one cost among others resulting from disinflation, as Filardo (1998) notes. Recessions associated with large inflation reductions not only lower GDP but also induce other costs that are much more difficult to measure: personal costs borne by the unemployed, failed businesses, or a widening of the income distribution.

${ }^{2}$ As Filardo (1998) notes, Okun's (1978) empirical works, as well as Gordon \& King's (1982), are based on the implicit assumption of a linear Phillips curve, an assumption that is quite restrictive and questionable. We will see later on that this assumption of linearity is also one of the limitations of the structural VAR methodology. However, unlike the Phillips curve approach, structural modelling allows for a distinction between exogenous shocks and endogenous reactions of the system.

${ }^{3}$ Ball (1994) applies his episode-specific methodology to 19 OECD member countries using annual data over the period 1960-1991, and then to a sub-group of 9 of these countries using quarterly data over the same period.

${ }^{4}$ See, for example, Jordan (1997), Neely \& Waller (1997) or Zhang (2005).

${ }^{5}$ As emphasized by an anonymous referee, assuming the demand disturbance to be a monetary shock for the considered period is a strong assumption. However, preliminary attempts using a three-variable model (including the short-term nominal interest rate) have reached the same conclusions as with our bivariate model. Besides, Cecchetti \& Rich (2001) however show that the imprecision in sacrifice ratio estimates increases with the number of endogenous variables. For these reasons, we concentrate solely on a two-variable system, and associate shifts in monetary policy with the aggregate demand shock.

${ }^{6}$ Demand shocks, especially monetary policy shocks, should distort the path of potential output and thus have an impact on the Nairu (Non-Accelerating Inflation Rate of Unemployment). In the case of EMU countries, Logeay \& Tober (2006) stress the dependence of the Nairu on actual unemployment, which entails the existence of "hysteresis effects". This hysteresis phenomenon implies the possibility of a long-run non-neutrality of monetary policy, as described in Ball (1999), Ball \& Mankiw (2002) and Zhang (2005). of Applied Economics, 22 (5), 601-621. DOI : 10.1080/02692170802287672 
${ }^{7}$ This assumption is also questionable since we have quarterly data: several recent empirical studies suggest that monetary impulses would affect the inflation rate with a lag of two to three months in the euro area.

${ }^{8}$ We should note however that the hypothesis of five optimal lags has proved relevant in some cases, which is why the VAR models have also been estimated using five lags. Results are not reported here, but they are close to those obtained using four lags, which attest to a certain amount of robustness in our results.

${ }^{9}$ Impulse response functions obtained with the short-run identifying restriction are available upon request from the authors. The responses of inflation and output to the supply shock are in line with those reached using the decomposition proposed by Blanchard \& Quah (1989). However, the cumulative response of output to the demand shock appears to be significantly positive in most countries, which would entail the existence of "hysteresis effects".

${ }^{10}$ Provided that we assume symmetry in the real short-run effects of monetary policy, i.e. equivalence between the positive effects of monetary expansion and the negative effects of restrictive monetary policy. This questionable assumption represents one of the limitations inherent in the VAR modelling approach.

${ }^{11}$ If we employ the short-run constraint described above, we get higher estimates of the average sacrifice ratio as well as higher values for their standard deviation. However, the evolution of the average sacrifice ratio and the dynamics of the standard deviation of rolling estimates over the period 1972:1-2003:4 are very similar to the conclusions reached with the long-run constraint.

${ }^{12}$ We have also used other indicators to evaluate the degree of dispersion within euro area sacrifice ratios: the simple spread (which measures the difference between the highest and lowest estimates of the sacrifice ratio at each date), or the spread between the average of the three countries with the highest and lowest sacrifice ratios (in order to adjust for the sensitiveness of the simple spread to outliers). Results are not reported herein, but these two alternative dispersion indicators broadly exhibit the same behaviour as the unweighted standard deviation: there is no clear evidence of a decrease in the dispersion of sacrifice ratios.

${ }^{13}$ Many theoretical and empirical studies, such as Akerlof et al. (1996, 2000), show that a moderate level of inflation could provide some "grease" to the price and wage setting process.

${ }^{14}$ Of course, our findings say nothing about the optimal rate of inflation, since we only analyse the short-term output costs of fighting inflation. Further empirical analysis should try to balance more precisely the relative costs and benefits of a zero inflation target versus a small positive inflation rate. of Applied Economics, 22 (5), 601-621. DOI : 10.1080/02692170802287672 